\title{
EN LOS ORÍGENES DEL MUSEO ARQUEOLÓGICO DE SEVILLA: DOS ESCULTURAS THORACATAS Y LA COLECCIÓN DE JUAN DE CÓRDOBA CENTURIÓN. UNA PROPUESTA DE IDENTIFICACIÓN
}

\author{
THE ORIGIN OF THE ARCHEOLOGICAL MUSEUM OF SEVILLE: TWO THORACATA SCULPTURES \\ AND THE JUAN DE CORDOBA CENTURION COLLECTION. A PROPOSAL OF IDENTIFICATION
}

\author{
JOSÉ RAMÓN LÓPEZ RODRÍGUEZ*
}

\begin{abstract}
Resumen: La formación del Museo Arqueológico de Sevilla arranca en esencia de dos colecciones, una del siglo XVIII y otra del XIX. En cada una de ellas existe una escultura thoracata que hemos podido identificar gracias a las referencias que poseemos. Una de estas dos esculturas era parte, junto con otras cuatro, de la colección de Juan de Córdoba, las cuales, por haberse olvidado su procedencia, se daban por perdidas. Se propone aquí una identificación de dichas esculturas basándose en los datos historiográficos existentes.
\end{abstract}

Palabras clave: Escultura, Thoracata, Lora de Estepa, Juan de Córdoba Centurión, Museo Arqueológico de Sevilla, Itálica, Ivo de la Cortina.

\section{INTRODUCCIÓN}

Existen en el Museo Arqueológico de Sevilla dos esculturas en mármol que representan sendos personajes en vestimenta militar. Ambas carecen de cabeza y parte de las extremidades. Son dos torsos que han estado en la colección del museo desde los inicios de la formación de la misma. Pero hasta aquí llegan sus semejanzas.

Queremos comenzar con la comparación de ambas piezas, lo que nos va a permitir asociarlas a los datos

\begin{abstract}
The creation of the Archeological Museum of Seville starts essentially with two collections, one is from the XVIII century, the other from the XIX. In each one of them, there exists a Thoracata sculpture which we have been able to identify thanks to some historiographical references consulted. One of the sculptures, along with other four, was part of an old collection that Juan de Cordoba Centurion put together. All of them, whose origin had been forgotten, were considered missing for some time. Here, we defend a proposal of identification of the sculptures shown currently at the museum.

Keywords: Sculpture, Thoracata, Lora de Estepa, Juan de Córdoba Centurión, Archeological Museum of Seville, Itálica, Ivo de la Cortina.
\end{abstract}

historiográficos conocidos y por tanto a su identificación, por medio de un acercamiento a las circunstancias de su origen y hallazgo.

No son las únicas piezas correspondientes a representaciones thoracatas que existen en la colección del museo, como se puede corroborar en el estudio que Concepción Fernández-Chicarro dedicó en su día al tema (1947). Sin embargo las dos esculturas que nos ocupan destacan con diferencia del resto debido al hecho de conservar la figura casi completa del personaje

\footnotetext{
* Conservador de museos. Correo-e: jr.lopez50@gmail.com.
} 


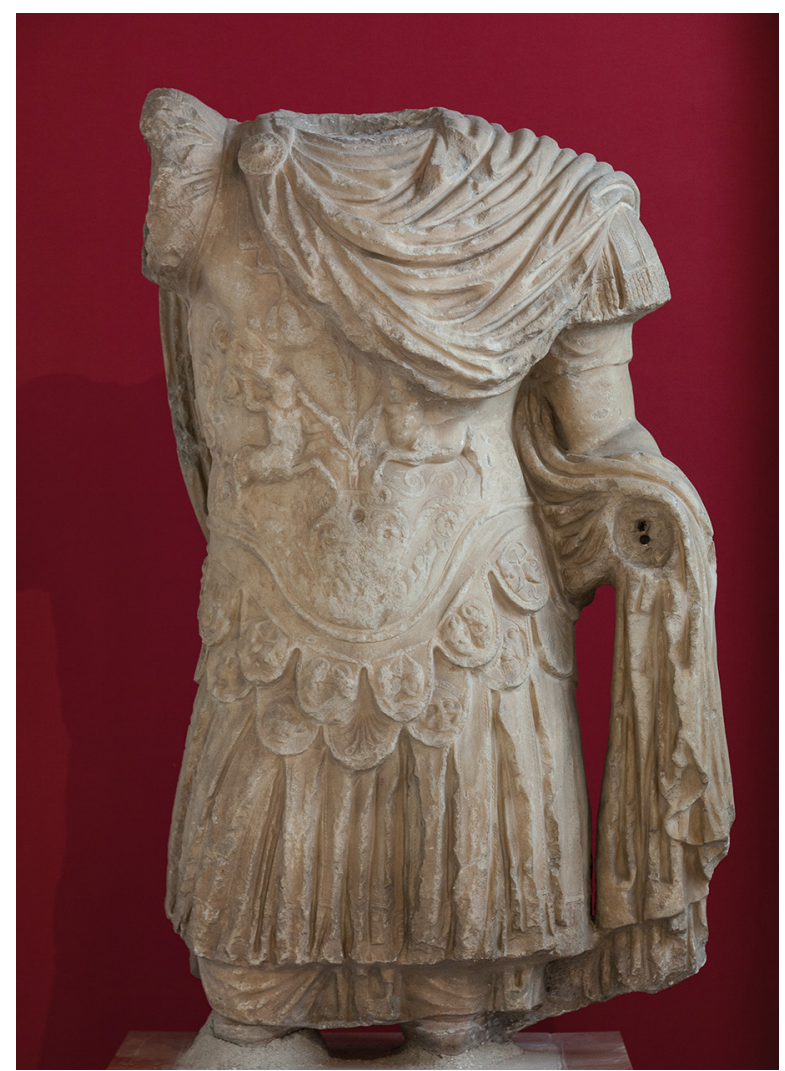

Figura 1. Escultura thoracata aparecida en Itálica en 1836. Museo Arqueológico de Sevilla con número de registro REP 104.

representado, seguramente imperial, desde el cuello hasta la mitad de los muslos, mientras que las demás incluidas en aquel estudio corresponden exclusivamente a fragmentos de mucha menor entidad. Por suerte las diferencias formales exteriores de estas dos esculturas militares están bien marcadas, por lo que no es fácil confundirlas. Pasemos a analizar pormenorizadamente cada una de ellas en su contexto.

\section{LA PRIMERA ESCULTURA THORACATA (REP 104)}

La primera es la escultura que en el museo lleva el número de registro de entrada REP-104. Se trata de un torso completo de un personaje en traje militar, al que le faltan la cabeza, las piernas desde las rodillas, el brazo derecho completo y la mano izquierda desde más arriba de la muñeca. Es de mármol de Almadén (León 1995: 38) y está en postura de arengar a las tropas (adlocutio), con el brazo derecho elevado. El paludamentum está sujeto cerca del hombro derecho por una fíbula en forma de roseta y cae sobre el hombro izquierdo y pecho (fig. 1).

Nótese, porque es importante, que el paludamentum cubre ampliamente el pectoral izquierdo de la coraza y es este uno de los detalles que lo diferencian a simple vista de la otra thoracata. Luego el manto cae por la espalda hasta la cintura, pasa sobre el antebrazo izquierdo y cae verticalmente a un costado, hasta la altura de las rodillas. Se aprecia claramente sobre el hombro derecho la cinta que servía para unir el peto con el espaldar, así como dos bisagras de unión de ambas piezas en el costado derecho.

La coraza o loriga presenta como decoración principal dos centauros barbudos afrontados que portan trofeos militares en actitud de clavarlos sobre el suelo. Ambos centauros, en una composición que resalta la simetría, se hallan separados por un motivo vegetal vertical que surge de una base de roleos vegetales que llenan toda la parte inferior de la composición. La línea de la coraza a la altura del vientre está muy marcada en la talla, y tras una franja lisa aparecen las pteryges, que están dispuestas en dos hileras. En la superior se suceden cabezas de elefantes afrontados con cabezas de carneros afrontados, a lo que hay que añadir dos palmetas en los extremos de la serie. En la fila inferior se alternan cabezas de Gorgona con palmetas y cabezas de Pan barbado.

La parte posterior de la figura está peor trabajada que el frente y muestra una espalda de forma aplanada, seguramente en relación al lugar al que estaba destinada, delante de un muro o en una hornacina. El brazo izquierdo muestra rehundida la zona de empalme con la muñeca y mano, con dos orificios para su engarce. En la parte trasera, en el lado izquierdo, existen dos orificios de sección cuadrada, no mencionados en la bibliografía, y que seguramente servían para acoplar la pieza a algún elemento de sujeción. El mayor de estos dos orificios está dentro de una acanaladura irregular y torpemente trabajada, que ha roto la escultura y su decoración en la zona de las launas, por lo que se puede suponer que ha sido realizada en una época posterior a la del uso original de la estatua.

Según García y Bellido (1949: 196), “es la pieza más fina de todas las de su especie y aventaja en riqueza a sus similares de Mérida" por "la delicadeza con que están labrados los repujados del peto". Se fecha en época claudia (León 1995: 38).

Todos los autores que han tratado de esta escultura mencionan que apareció en Itálica. Sin embargo se aprecian ciertos titubeos cuando toca pronunciarse 
sobre cuándo y cómo apareció. Concepción Fernández Chicarro, la primera en hablar de ella, dice: "Procede de Itálica (Sevilla), en cuyas ruinas se encontró, al parecer, a mediados del siglo pasado; debiendo ingresar en el Museo hacia 1890, por lo que se colige del Registro de entrada (número 104) de Don Manuel Campos, primer Director del Centro" (1947: 130-131).

Un poco después, Antonio García y Bellido (1949: 195) repitiendo que apareció "al parecer" a mitad del siglo XIX, precisa un poco más el último dato: "Ingresó en 12 de marzo de 1880". Más adelante Paloma Acuña al estudiar en su tesis doctoral la escultura militar hispana (1975: 59), zanja de modo tajante la cuestión al afirmar sucintamente: "Lugar de procedencia: Ruinas de Itálica (Sevilla). Año 1880", lo que se podía interpretar sin duda como el año del hallazgo.

Y lo más curioso es que, aparentemente sin argumentos, desde un primer momento se enlaza esta escultura thoracata con la otra a la que aquí también nos referimos, equiparándolas en cronología, procedencia, circunstancias de hallazgo y fecha de ingreso, etc. Ya lo había insinuado Demetrio de los Ríos, cuando entre las ilustraciones para su obra inconclusa sobre Itálica, incluyó en una misma lámina estas dos esculturas thoracatas, asignando por lo tanto una procedencia italicense a la segunda y una equiparación tácita de ambas (Amores Carredano y Beltrán Fortes 2012: 255). En continuidad con esta idea, Fernández Chicarro (1947: 132) dice de la segunda: "debió hallarse en la misma época que el torso anterior, ingresando en el Museo en la misma fecha", lo que es asumido por el resto de los autores, como por ejemplo Antonio García y Bellido en su gran síntesis sobre Itálica (1960: 154) donde dice de este torso que ahora nos ocupa: "probablemente hallado con el anterior cuyas proporciones son las mismas. Ambos ingresaron en el Museo de Sevilla en la misma fecha".

La coincidencia de la fecha de ingreso para ambas esculturas tiene una explicación bien fácil, por obvia. En efecto, ambas fueron anotadas en el libro de registro en la misma fecha, aunque realmente se hallaban en el edificio del museo desde hacía muchos años. En 1879 y por real orden de 21 de noviembre, se creó el Museo Provincial de Antigüedades de Sevilla junto a los de Barcelona, Granada y Valladolid, contando para su constitución con los fondos que había reunido hasta entonces la Comisión Provincial de Monumentos. En el caso sevillano se trataba de 335 objetos de todo tipo, que se encontraban depositados en el Museo de Pinturas cuando se creó el de Antigüedades y que fueron incluidos en el libro de inventario en 1880 por el primer director que tuvo la institución, Manuel Campos Munilla, después de recibir oficialmente de la Comisión Provincial de Monumentos el citado conjunto de objetos arqueológicos.

Lo cierto es que poco a poco se había ido creando un tejido de suposiciones y sobreentendidos que daban por ciertos hechos poco probados y que a duras penas lograban ocultar el desconocimiento de las circunstancias de los hallazgos de ambas piezas que manifiestan todos estos autores. Desconocimiento del que ciertamente ellos no eran culpables, pues hacía muchas décadas, un siglo o más, que se había perdido la memoria de todos los datos y acontecimientos relativos al hallazgo e incorporación de ambas piezas.

Nadie recordaba ya que esta escultura REP 104 había aparecido a principios del mes de abril del año 1836 en "la construcción de un trozo de carretera entre Santiponce y sus heras (sic)", según publicó el Diario de Sevilla de Comercio, Artes y Literatura en una noticia fechada el 9 de abril, que fue recogida por otros periódicos de Madrid, como era habitual.

En ella se da cuenta de la aparición de dos esculturas, una de un "general romano" según se infiere de su "armadura", o lo que es igual, una figura thoracata, tratándose la otra del busto sobre peana del emperador Adriano, que ahora se exhibe en el museo arqueológico hispalense y que, como puede verse en el párrafo siguiente, no fue acertadamente identificado en el momento de su aparición.

Uno de los textos que se hacen eco de lo publicado por el diario sevillano reza como sigue:

"Antigüedades. Acaba de encontrarse en las escavaciones que se están haciendo, para la construcción de un trozo de carretera entre Santiponce y sus heras, dos magníficas estatuas al parecer de alabastro: la una se halla tan mutilada que no conserva la cabeza, piernas ni brazos, indicándose solamente por los geroglíficos y relieves de que está adornada su armadura, ser de alguno de los generales de la que fue Reina del mundo: y la otra es de medio cuerpo, colocada en su correspondiente pedestal, está entera, su cabeza es elegante y bella, ciñendo el cuerpo como un manto consular; según las apariencias se cree será de alguno de los desgraciados hijos de Pompeyo. Ambas estatuas están depositadas en el patio llamado de las Musas, por el ingeniero don Valentín María del Río. A los amantes de las bellas artes y a los investigadores de la misteriosa antigüedad, se les ha presentado objeto en que satisfacer su curiosidad con tan precioso invento, que por su mérito de antigüedad y artístico debe colocarse en el museo, que se prepara en esta ciudad, como trofeos de la gloria que brilló en 
el suelo, en los primitivos tiempos. (Diario de Sevi1la)" (Semanario Pintoresco Español, Madrid, 24 de abril de 1836).

Ambas esculturas habían aparecido en las obras de construcción de la variante de la carretera a Extremadura a su paso por Santiponce. El trazado anterior de esta carretera debería de discurrir por la cota más baja, bordeando la población por su lado este, el cual era fácilmente alcanzable por las subidas del río, en caso de producirse. El nuevo trazado discurría por una cota más alta, hacia el oeste, y evitaba este problema. El caserío de Santiponce en aquella época ocupaba solamente una pequeña parte del yacimiento, por lo que el nuevo trazado de la carretera por el oeste originó un enorme destrozo arqueológico, seccionando de norte a sur la ciudad romana de Itálica.

Esta noticia del Diario de Sevilla es la primera referencia que hemos encontrado en la prensa del momento relativa a esta carretera a Extremadura, cuya construcción duró décadas a lo largo del siglo y que fue en parte responsable de continuados episodios de destrucción del yacimiento romano puesto que, además de lo ya mencionado al construir la variante a su paso por Santiponce, se recurrió a la muralla y al anfiteatro de Itálica para obtener materiales con los que efectuar el asentamiento del firme, como ha sido ya ampliamente publicado (Luzón Nogué 1999: 83-85; López Rodríguez 2012: 54).

La verdad es que no existen muchas noticias sobre la obra pública de carácter utilitario en estos momentos, ni aquí ni en otras partes. Sin embargo es posible que el mal estado de las carreteras de la zona hiciera de esto un tema prioritario, a pesar de la carestía de inversiones. Sólo así podemos entender que a la par que se ha iniciado esta carretera en Santiponce, la Diputación de Badajoz publique una resolución por la que todos los ayuntamientos de la provincia tendrán que recomponer las carreteras de su término, aportando todos los habitantes cuatro horas de trabajo cada uno los domingos y festivos por la mañana (Boletín Oficial de la Provincia de Badajoz, $\mathrm{n}^{\mathrm{o}} 23$ de 23 de febrero de 1836), medida que no sabemos si fue muy eficaz, pero desde luego no se puede negar que barata en mano de obra sí que salía a las arcas públicas.

La construcción de esta variante de Santiponce no pudo comenzar hasta que no se ejecutó la desamortización eclesiástica de los primeros años del reinado de Isabel II, puesto que el trazado cruzaba terrenos que eran del monasterio de San Isidoro del Campo, los cuales como consecuencia de la desamortización pasarán a titularidad pública y serán gestionados por Gobierno Civil de la provincia.
Un real decreto de 25 de julio de 1835 suprimía “los monasterios y conventos de religiosos que no tengan 12 individuos profesos, de los cuales las dos terceras partes a lo menos sean de coro" (Gaceta de Madrid $\mathrm{n}^{\mathrm{o}} 211$, de 29 de julio de 1835), el cual no se publicaría en el Boletín Oficial de la Provincia de Sevilla hasta casi un mes más tarde, en el n 371 de 21 de agosto de 1835. Al poco tiempo vemos cómo comienzan a aparecer en el Boletín Oficial de la Provincia de Sevilla convocatorias para subasta de diferentes efectos pertenecientes a este monasterio poncino, como la cosecha de aceituna de todos sus olivares, o todo el ganado, bueyes, becerros,... 695 ovejas, 230 carneros, 79 cerdos..., etc., y también "una huerta y su puebla" (Boletín Oficial de la Provincia de Sevilla no 397 de 21 de septiembre de 1835). También salieron a subasta de arrendamiento todos los terrenos del monasterio, lo cual dio pie a una reclamación del ayuntamiento de Santiponce que vamos a copiar aquí por ser novedad de sumo interés, pues ha condicionado desde este año de 1835 el desarrollo posterior del municipio y por tanto del yacimiento romano de Itálica, ya que aquí comenzó la parcelación del mismo. El Boletín Oficial de la Provincia de Sevilla n $^{\circ} 398$ de 22 de septiembre de 1835 publica lo siguiente:

"Extracto de las disposiciones de la Junta directiva adoptadas en el día 21. Habiendo tratado un particular de tomar en arriendo todo el caudal del monasterio de Santiponce, ocurrió (sic) el ayuntamiento de aquella villa a la Junta manifestándole las desventajas que se irrogaban a aquel pueblo de tal contrato, pues sus vecinos quedarían consiguientemente en el estado de dependencia que siempre habían sufrido del monasterio; y con el fin de que pudiesen mejorar su condición como arrendatarios de pequeñas porciones, proponía el mismo cuerpo municipal hacer por sí el arrendamiento de dichos bienes distribuyéndolo en fracciones proporcionadas entre sus administrados. La Junta encontró laudable y benéfico este proyecto y acordó que se realizase".

Lo cierto es que a partir de la secularización del monasterio de Santiponce, las diferentes instancias oficiales como el intendente, el director general de Rentas y Arbitrios de Amortización y sobre todo el gobernador civil, disponen de los bienes de dicho monasterio. Ahora es el momento en que se puede acometer sin cortapisas el nuevo trazado de la carretera atravesando los terrenos que fueron de propiedad eclesiástica. Aunque no sabemos el momento exacto de inicio de las obras, pensamos que la aparición de estas dos esculturas, la thoracata y el retrato de Adriano, ocurre al principio de las mismas, 
como puede suponerse de la mención a esta carretera en la noticia de prensa como "de Santiponce a sus heras", que estaban inmediatas a la población, siendo éste el primer hallazgo de importancia que se produce, o al menos que es conocido por el gran público.

El ingeniero que dirige las obras es Valentín María del Río, el cual, ante la importancia de estas dos esculturas "de alabastro", decide encontrar un lugar en el mismo Santiponce donde guardarlas para protegerlas, y lo más inmediato que tiene es "el patio llamado de las Musas". Se trata del espacio donde estuvo el malogrado "mosaico del circo" o "de las musas", el mismo que dibujara el viajero Alejandro Laborde (1802), aparecido casualmente en 1799. Está situado a no muchos metros del lugar del hallazgo de las esculturas y es un emplazamiento válido para la protección por estar cerrado con una tapia. Esta tapia se había construido justamente para defender el mosaico del circo, costeada de su bolsillo por el abogado sevillano Francisco Espinosa y que "de algún modo le resguardó por algún tiempo de las injurias del cielo y de la tierra: no asi de las de los hombres, pues hoy se halla absolutamente destrozado por su malicia e ignorancia", en palabras de Justino Matute y Gaviria (1827: 53), quien todavía había llegado a ver parte del mosaico y sacar un dibujo de él en 1818, con la ayuda de Francisco Javier Delgado (Ibíd:: 54). En 1835 no debía quedar ya nada del mosaico, si atendemos a una descripción que proporciona una "Guía de forasteros de la ciudad de Sevilla" de la época (Herrera Dávila 1832: 2: 78), aunque las tapias que lo cercaban, según vemos, siguieron prestando un gran servicio a la Arqueología.

Las obras de la carretera siguieron durante los años siguientes y hemos de suponer que las dos esculturas permanecieron en el "patio de las Musas" durante un tiempo. En el año 1838 llegó a Sevilla Ivo de la Cortina Roperto, funcionario del Ministerio de Gobernación, destinado como oficial al Gobierno Político de Sevilla. Era un "joven de no escaso ingenio y de grande amor a las antigüedades", en palabras de José Amador de los Ríos (1845), y que reunía muchas habilidades, pues era pintor de formación, dominaba varios idiomas y estuvo implicado en temas de arqueología prácticamente toda su vida, logrando un reconocimiento internacional.

Antes de llegar a Sevilla, Ivo de la Cortina había estado destinado desde 1836 en el Gobierno Político de Badajoz, interesándose en este tiempo por las antigüedades de Mérida. Por real orden de 11 de abril de 1838 , prorrogada en julio, se le concedió una comisión especial para estudiar el territorio de Mérida y sus monumentos, realizar excavaciones y fundar un museo de
Arqueología (Canto de Gregorio 2010: 819). Por eso, la llegada de Ivo de la Cortina al Gobierno Político de Sevilla tuvo que producirse en el otoño de ese año 1838 y no antes, seguramente coincidiendo con el cambio de jefe político que tiene lugar en Sevilla entre noviembre y diciembre de 1838. Durante casi todo el año 1838 fue jefe político de la provincia de Sevilla Serafín Estébanez Calderón, hasta el 11 de noviembre de 1838. El 9 de diciembre toma posesión su sucesor, Francisco Alejandro Fernel, el cual ocuparía el puesto sólo hasta mitad de enero de 1839. Le sucede Joaquín Manuel de Alba, que tomó posesión un mes más tarde, el 14 de febrero de 1839 (datos obtenidos del Boletín Oficial de la Provincia de Sevilla de esas fechas).

Ya en Sevilla, pronto llamó la atención de Ivo de la Cortina lo que estaba apareciendo en Santiponce y por ello, días antes de que cesara Francisco Alejandro Fernel como jefe político, presentó una memoria que lleva fecha de 7 de enero de 1839, solicitando realizar excavaciones en el yacimiento que estaba en esos momentos siendo gravemente afectado por las obras de la variante de la carretera de Extremadura (Canto de Gregorio 2010: 819).

Aunque el nombramiento por real orden de Ivo de la Cortina como director de las excavaciones no llegó hasta el 30 de enero de 1839 (Fernández Gómez 1998: 90-91), estas comenzaron realmente el día 19 de enero (Gaceta de Madrid, 16 de abril de 1839), pues fueron autorizadas por el jefe político Francisco Alejandro Fernel, poco antes de dejar el cargo:

"El oficial segundo tercero de este gobierno civil Don Ivo de la Cortina presento al Sr. Fernel, último jefe político, una memoria acerca de la importancia que podrían adquirir las artes en desenvolver las magníficas ruinas de Itálica. [...] Las reflexiones del Sr. de la Cortina no pudieron menos de hallar acogida en su gefe, entusiasta también y aficionado a los trabajos arqueológicos. [...] Al efecto el oficial Cortina fue encargado de dar principio a las excavaciones, asociado con el párroco de Santiponce'; a este efecto se puso a sus órdenes una brigada de presidiarios del peninsular de esta ciudad" (Gaceta de Madrid, 14 de febrero de 1839, reproduciendo un texto de Diario de Sevilla de Comercio, Artes y Literatura de 3 de febrero del mismo año).

1. Se trataba de José Toro Palma, que había sido prior del monasterio de San Isidoro del Campo y que tras la desamortización de 1835 había quedado residiendo en dicho monasterio con funciones de párroco. A él dedica José Amador de los Ríos elogiosas palabras en el prólogo a su obra manuscrita de 1845 
Los trabajos comenzaron por el edificio de las Termas Menores y otro al suroeste de las mismas que llama "templo de Venus", para terminar finalmente en la zona del foro, que es la que más dañada había quedado por las obras de la carretera. D. Ivo emitía informe mensual con los resultados de estas excavaciones, con destino a su superior el jefe político y con copia a las Reales Academias de San Fernando y de la Historia. A su vez el jefe político elevaba estos informes al Secretario del Despacho de Gobernación, siendo alguno de ellos publicado en la Gaceta de Madrid, a lo que hay que sumar las noticias que aparecían en prensa dando cuenta de los hallazgos.

Gracias a ello sabemos que lo que fue apareciendo en la intervención de D. Ivo de la Cortina en Itálica se trasladó al edificio del Gobierno Político de Sevilla desde prácticamente el comienzo de los trabajos ( $G a$ ceta de Madrid de 6 de abril de 1839, reproduciendo un texto de El Sevillano de 27 de marzo). Pensamos que, si no se habían llevado antes, este pudo ser el momento en que se trasladan también las dos estatuas aparecidas en 1836 y que estaban en el recinto de "El Patio de las Musas". De hecho encontramos incluidas las dos esculturas en la relación de objetos que se hallan en el Archivo del Gobierno Político y su almacén, que fue redactada por el propio Ivo de la Cortina y que transcribe Aurelio Gali Lassaletta (1892: 209). Hay que señalar también que en todas las relaciones de piezas halladas en Itálica, publicadas por Ivo de la Cortina en la prensa del momento siguiendo el curso de sus trabajos, no figura ninguna otra escultura en traje militar, por lo que se corrobora que la escultura thoracata depositada en los almacenes del Gobierno Político de Sevilla es la aparecida en 1836.

Se formó por tanto en la sede de este Gobierno Político una interesante colección arqueológica que pronto fue objeto de atención de las instituciones culturales de la ciudad, especialmente la Academia Sevillana de Buenas Letras, que se implicó desde su comienzo en las excavaciones de Ivo de la Cortina en Itálica. De este modo, ya desde marzo de $1840 \mathrm{Ma}-$ nuel María del Mármol, director de esta Academia, solicita al jefe político de la provincia el depósito de los objetos aparecidos en Itálica, tanto lo que se comenzaban a depositar en el Gobierno Político como lo que procedente de la colección de Bruna se hallaba en el Alcázar, al objeto de formar con ello un "gabinete" en un edificio que se esperaba le fuera concedido. Meses después, con fecha de 21 de octubre de 1840, la Junta de Gobierno de la Provincia de Sevilla cedió a la Academia una parte del edificio de Santa
María de Gracia para establecer el museo y clases de enseñanza (RASBL, Carpeta 35, Expediente "Excavaciones de Itálica (1835-1846)"). La respuesta a las aspiraciones de la Academia llegó por un oficio del jefe político de fecha 19 de agosto de 1840, con el que se resolvía se entregasen a la Academia los objetos de Itálica para hacer con ellos un museo. A pesar de ello, el expediente se trasladó para consulta a la Real Academia de la Historia, cuyo dictamen no fue favorable, y como conclusión se dictó una real orden de 4 de diciembre de 1840 dirigida a la Junta de Museo en la que, frente a la solicitud de la de Buenas Letras "de que se le entreguen los objetos que se van extrayendo de las excavaciones de Itálica para formar un Museo de arqueología", se resolvía "por considerarlo más económico y ventajoso, que el Museo de arqueología forme parte del Provincial" (CPMHAS, Carpeta "Antecedentes del Museo Arqueológico de Sevilla").

Se da la circunstancia de que, con independencia de las gestiones que había realizado la Academia Sevillana de Buenas Letras, la Junta de Museo de Sevilla, que ahora recibía el encargo de la gestión de las piezas arqueológicas, había ya por su cuenta acordado reclamar los objetos de Itálica que se encontraban en la sede del Gobierno Político de la ciudad, en sus sesiones de 11 y 19 de junio de 1840 (CPMHAS, Libro I de Actas, pp. 32-34). Sin embargo la Junta de Museo se encontró con las mismas dificultades con las que había topado la Academia: la completa falta de medios para afrontar el traslado de las piezas y su instalación en forma de museo. Por ello fue pasando el tiempo hasta que dos años más tarde, en sesión de 13 de julio de 1842, tras varias reclamaciones del jefe político, la Junta acordó que uno de sus vocales, el marqués de Arco Hermoso, "reconozca y reciba los objetos arqueológicos extraídos de las excavaciones de Itálica, que deben formar parte del Museo arqueológico" (CPMHAS, Libro I de Actas, p. 90).

Pocos días después se procedía a la entrega de los objetos arqueológicos depositados en el Gobierno Político, que quedó reflejada en un inventario de fecha 22 de julio de 1842, firmado por Antonio Cabral Bejarano como conservador del Museo de Pinturas, cuya copia se conserva en el archivo del Museo Arqueológico de Sevilla. En este inventario encontramos efectivamente la escultura thoracata a que nos estamos refiriendo, descrita de esta forma:

\footnotetext{
"Cuerpo sin los cuatro miembros ni la cabeza, que representa un guerrero, según su traje, mayor que el natural".
} 
Lo trasladado se colocó en el claustro mayor del edificio del ex convento de la Merced, en donde por aquel entonces se acababa de terminar la instalación del Museo de Pinturas. Las piezas fueron abandonadas tumbadas en el suelo de los corredores de este claustro sin ningún tipo de distribución ni orden, lo que haría comentar a Richard Ford, en su famoso "Handbook", siempre tan mordaz, que aquello parecía el patio de un picapedrero: "In the Museo are heaped up, as in a stonemason's yard, a few antiquities of a low art, found in some road-making and accidental excavation at Italica" (Ford 1855: I: 72). Así fue cómo estas piezas procedentes del Gobierno Político se constituyeron en 1842 en el fondo inicial para la formación de un futuro Museo Arqueológico de Sevilla, al que aún le quedaba un largo camino que recorrer.

\section{LA SEGUNDA ESCULTURA THORACATA (REP 107)}

Exteriormente esta segunda escultura thoracata, que lleva el número de registro del Museo Rep-107, presenta una superficie mucho más deteriorada y erosionada que la anterior, lo que podría ser indicio de que ha tenido una trayectoria diferente como objeto arqueológico (fig. 2).

Se trata de un torso que representa a un emperador romano en traje militar. Mide más de un metro de alto y es de mármol, probablemente de Paros (Rodá de Llanza 1997: 179). Se conserva desde el cuello hasta la mitad de los muslos, careciendo de cabeza, brazos y resto de las piernas. Viste túnica, que asoma en su hombro izquierdo y sobre ella la loriga, ampliamente decorada. El motivo central en la misma lo constituyen dos Victorias afrontadas con un trofeo entre ambas. Por encima del trofeo y cerca del cuello hay una máscara de Gorgona. Bajo las Victorias parece adivinarse una decoración vegetal que se extiende a los laterales. Sobre la loriga porta un manto sujeto en el hombro izquierdo que cae ligeramente sobre el pecho y se extiende luego hacia la espalda, la cual está someramente tratada. Nótese que a diferencia de la thoracata anterior, en esta el manto deja al descubierto los dos pectorales de la loriga, los cuales, simplificando, muestran dos líneas curvas semejantes, que con la iluminación adecuada proyectan una sombra marcada.

Tras la gruesa línea de remate inferior de la loriga corre un friso decorado con temas de armas, y luego se suceden los lambrequines que corren en dos hileras. La superior está decorada con gorgonas, cabezas de carnero

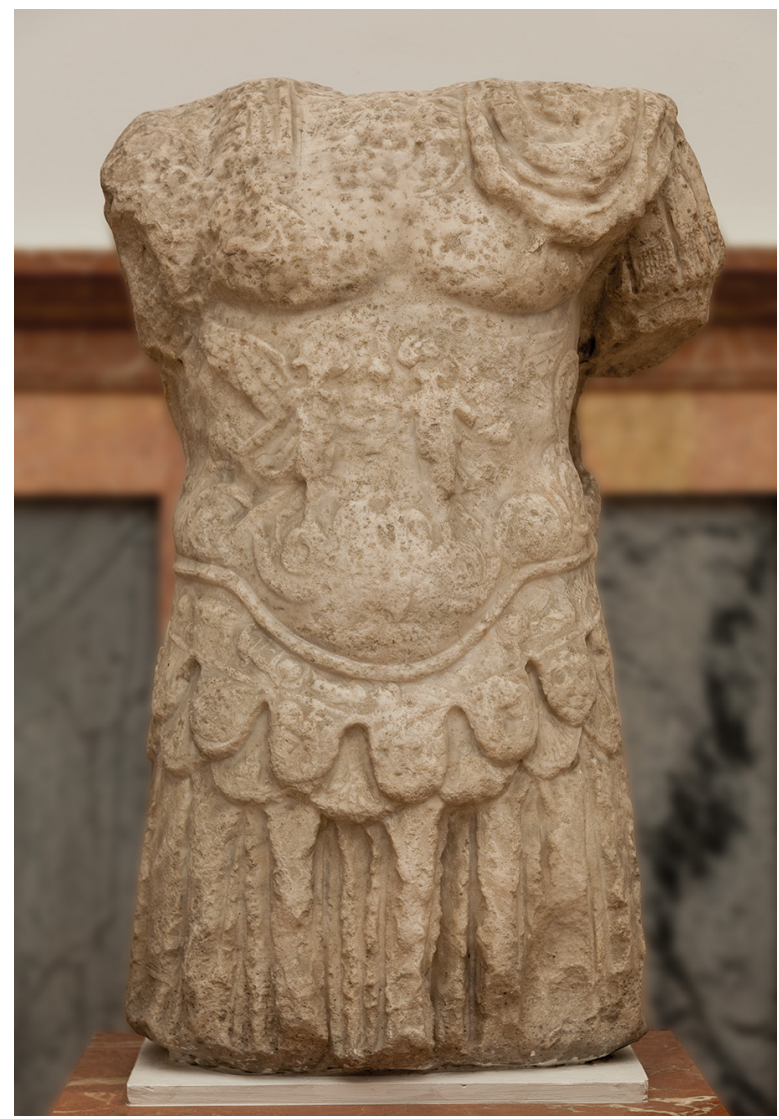

Figura 2. Museo Arqueológico de Sevilla. Escultura thoracata con el número de registro REP 107, procedente de Estepa y que formó parte de la colección de Juan de Córdoba Centurión.

y motivos vegetales; la inferior, por palmetas. Toda la decoración de esta escultura está muy deteriorada.

Al igual que en el caso anterior, los autores mencionados más arriba que han tratado el tema han pensado que esta escultura procedía de Itálica por las razones que antes expusimos, al equiparar ambas piezas en fecha de hallazgo, procedencia, etc. Pero no existe ningún argumento que sostenga esta identificación, porque es evidente que también en este caso se ha perdido toda referencia a las circunstancias de ingreso de esta pieza.

Por eso tenemos que recordar que la documentación histórica menciona una pieza thoracata que debería estar en el museo de Sevilla y que se encuentra a la espera de identificación, o al menos no se ha sabido reconocer hasta ahora. Es una de las esculturas que ingresó en el museo procedente de lo reunido por Francisco de Bruna en el Alcázar de Sevilla. En concreto nos estamos refiriendo a una de las esculturas que habían sido parte de la colección que Juan de Córdoba Centurión 


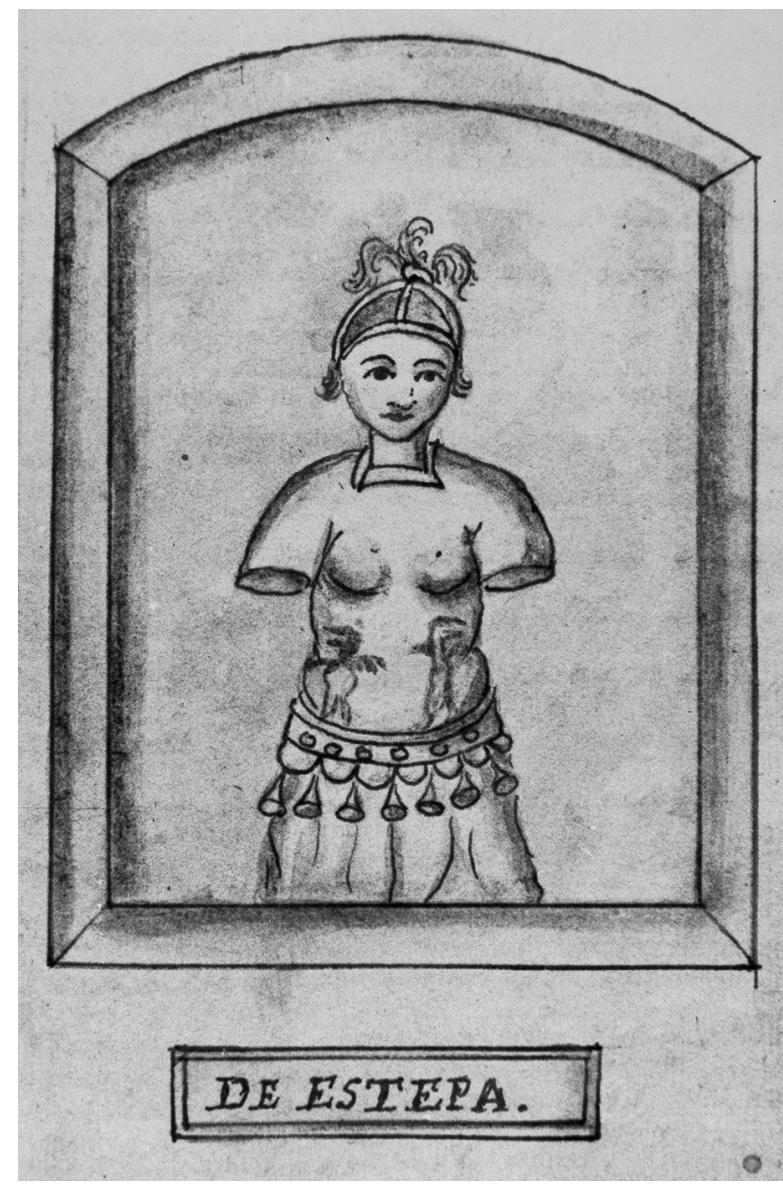

Figura 3. Representación de la segunda estatua en la colección de Juan de Córdoba Centurión, según dibujo de fray Alejandro del Barco.

formó en el siglo XVII en su casa-palacio de Lora de Estepa, la cual Francisco de Bruna trajo en 1789 de aquella población a Sevilla.

Centrémonos por el momento en esta pieza dentro de la colección de Juan de Córdoba. Contamos con dos fuentes para conocer las características de esta colección. La primera es la obra manuscrita dedicada a la historia de la ciudad de Estepa y sus familias nobles que escribió el padre Juan de San Román Muñoz, comenzada su redacción en 1716. La segunda es el manuscrito que fray Alejandro del Barco redactó avanzado el siglo XVIII haciendo la historia del marquesado de Estepa, en cuyo capítulo XV trata de este conjunto de objetos arqueológicos, afortunadamente con ilustraciones, tanto de las lápidas como de las cinco esculturas que se hallaban en Lora de Estepa.

Gracias a estos dibujos, creemos poder identificar de forma plausible la escultura a la que nos estamos refiriendo (REP 107) con la thoracata que poseía Juan de Córdoba Centurión en Lora de Estepa. Se trata de la nombrada como "segunda estatua" en el manuscrito de Alejandro del Barco (1994: 222) (fig. 3).

Antes de nada creemos necesario hacer una llamada de atención sobre la forma de representar las esculturas en este manuscrito, que no solamente no es muy precisa sino que tiene además una particularidad curiosa. Como se puede ver, en el dibujo la escultura posee cabeza cubierta con casco, cabeza que falta en la pieza real. Igual ocurre en otras dos de las representadas que veremos más adelante. Creemos que se ha hecho así, añadiendo al dibujo una cabeza imaginada, para dar verosimilitud al personaje representado, llamado por los vecinos de Lora "El Gran Pompeyo" y que Barco sospecha se trate del dios Marte. Esta alteración en la representación tampoco nos debe de extrañar, pues tenemos ante nosotros los dibujos que San Román Muñoz hizo de las dos primeras esculturas de la colección de Lora, donde la distancia con lo representado es aún mayor.

Si dejamos por tanto a un lado la cabeza, observamos que existen evidentes coincidencias entre lo representado en este dibujo y la escultura thoracata del Museo Arqueológico de Sevilla. Se trata de una figura en traje militar, carente de brazos y de piernas, con los pectorales de la loriga muy marcados, no estando el pectoral izquierdo oculto por el manto. Dicha loriga está adornada con dos victorias, burdamente dibujadas. Por debajo corre un friso y luego los lambrequines, habiéndose destacado la fila inferior, correspondiente a las palmetas, y que aquí se han dibujado muy simplificadas.

Juan de Córdoba, en un inusitado ejemplo de modernidad, colocó cartelas junto a las piezas de su colección. En este caso, tal como aparece en la ilustración del manuscrito de Alejandro del Barco, la cartela reza "DE ESTEPA". No procede pues esta escultura de Itálica, como se ha tenido hasta ahora, sino de la población de Estepa.

Una vez fallecido Francisco de Bruna en 1807, su colección arqueológica quedó en el Alcázar sometida a un futuro incierto, lo que incluía su envío a Madrid para sumarse a la colección real o su integración en la colección de los duques de Montpensier, recientemente instalados en Sevilla. Finalmente y tras las correspondientes reclamaciones tanto de la Academia Sevillana de Buenas Letras como de la Comisión de Monumentos, esta última se hizo cargo de la misma para incorporarla a lo ya reunido en el claustro del edificio del Museo de Pinturas (López Rodríguez 1995; López Rodríguez 2010: 199-202). 
El traslado de las piezas se realizó en 1855 , formalizándose inventario con fecha de 25 de julio de lo que el alcaide de los Reales Alcázares, Alonso Núñez de Prado, entregaba a Antonio Cabral Bejarano, director de la Escuela de Bellas Artes. En dicho inventario figura con el número 21 nuestra escultura: "Torso de un guerrero con armadura, mal tratado" (Romero Murube 1965: 91-93). Es la única escultura en traje militar de este inventario que refleja lo que se encuentra en el Alcázar, la cual está en mal estado de conservación, con lo que cualquier duda que pudiera haber sobre que esta sea la que trajo Bruna procedente de Lora de Estepa queda despejada.

Y así fue como desde aquel momento, junto a las demás piezas, la escultura thoracata que estamos tratando pasó a formar parte de la colección arqueológica reunida en el Museo de Pinturas, colección que años más tarde sería núcleo fundador de Museo de Antigüedades de Sevilla.

\section{EL MUSEO DE JUAN DE CÓRDOBA CENTURIÓN EN LORA DE ESTEPA}

El primer poseedor de la escultura anterior fue Juan de Córdoba Centurión (hacia 1620 - 1665), hijo ilegítimo del tercer marqués de Estepa, Adán Centurión, quien lo había educado con esmero en las humanidades. Ocupó diferentes cargos públicos, como oidor de la Audiencia de Sevilla y de la de Valladolid. Tan aficionado a las antigüedades como su padre, Juan de Córdoba se propuso recoger los restos romanos que se hallaban en los territorios de su marquesado, formando una importante colección que colocó en la villa o casa de recreo que había hecho construir en Lora de Estepa (López Rodríguez 2010: 79-83).

Los ejemplares epigráficos los colocó en un gran salón, en la crujía de fachada del palacio, mientras que las esculturas, que eran cinco, fueron colocadas en nichos en el muro de acceso a los jardines traseros. Es algo que podemos imaginar ejecutado a semejanza de lo realizado por el arquitecto Tortello en la residencia de los duques de Alcalá en Bornos, donde el acceso a los jardines limita con un muro con nichos en los que se colocaron las estatuas (fig. 4) (Calleja Marchal 1999). En la fachada del palacio de Lora se colocó una lápida latina fechada en 1659, en la que se expresa en breves palabras todo un programa museológico tal como se entendía a mitad del siglo XVII (López Rodríguez 2010: 80).

Como se dijo antes, tenemos dos fuentes que hablan de esta colección. La primera es la obra del padre Juan de San Román Muñoz, de 1716. La segunda es otra historia de Estepa, también manuscrita, de la pluma de fray Alejandro del Barco, fechada en 1788, la cual, por ser más explícita en cuanto a la colección de Juan de Córdoba y poseer unos dibujos más fieles al natural, es la que seguimos aquí. Es necesario advertir que no existe, en lo que se refiere a las esculturas de esta colección, coincidencia entre las dos obras mencionadas, que se distancian en el tiempo unos cincuenta años. El manuscrito de San Román, a pesar de ser muy explícito en cuanto a la epigrafía, solo aporta los dibujos de tres de las esculturas, y únicamente coincide, en cuanto a numeración, con el de Alejandro del Barco en las dos primeras de ellas. No existe sin embargo coincidencia en estas dos fuentes respecto al orden de colocación y en la procedencia de las otras tres esculturas, puesto que una de las mencionadas como de Estepa por el segundo es atribuida a Lora de Estepa en el primero. Además llama mucho la atención la manera en que están representadas las figuras en el manuscrito más antiguo, de una forma manifiestamente imaginada y alejada de lo que entenderíamos hoy por un documento vinculado a lo representado. Las ilustraciones de Alejandro del Barco, con algunas matizaciones, parecen mucho más cercanas a la realidad y por lo tanto más útiles para un trabajo historiográfico, como hemos podido reseñar para la escultura thoracata anteriormente comentada. Sin embargo es preciso añadir que los dibujos de este autor están hechos de memoria, porque cuando está redactando el manuscrito hace dos años que no ha visitado el lugar, según menciona en un pasaje.

En 1788, enterado Francisco de Bruna de que Alejandro del Barco había realizado unos dibujos de las estatuas existentes en Lora de Estepa, le pidió le remitiese una copia. Así lo hizo, y según relata, en la carta de respuesta le dio cuenta del "estado en que se encontraba la casa, el abandono y desprecio con que se miraban estas preciosidades por falta de conocimiento de la estimación que se merecen y suplicaba que valiéndose de su autoridad y comisión, dispusiera que se extrajesen de alli y se trasladasen al Real Alcázar de Sevilla" (Barco 1994: 249). Fue Bruna a Estepa el 17 de mayo de 1789, visitando a fray Alejandro en su celda, y a raíz de aquí se produjo el traslado de la citada colección desde Lora a Sevilla, para integrarse en la "Colección de Antigüedades de la Bética" que estaba formado.

D. Antonio Ponz menciona las esculturas de la colección de Lora de Estepa, pues las vio en el Alcázar de Sevilla: "Todos estos fragmentos se hallan actualmente colocados en la galería que da ingreso a los salones del Alcázar". Sin embargo a la hora de describirlas sigue 


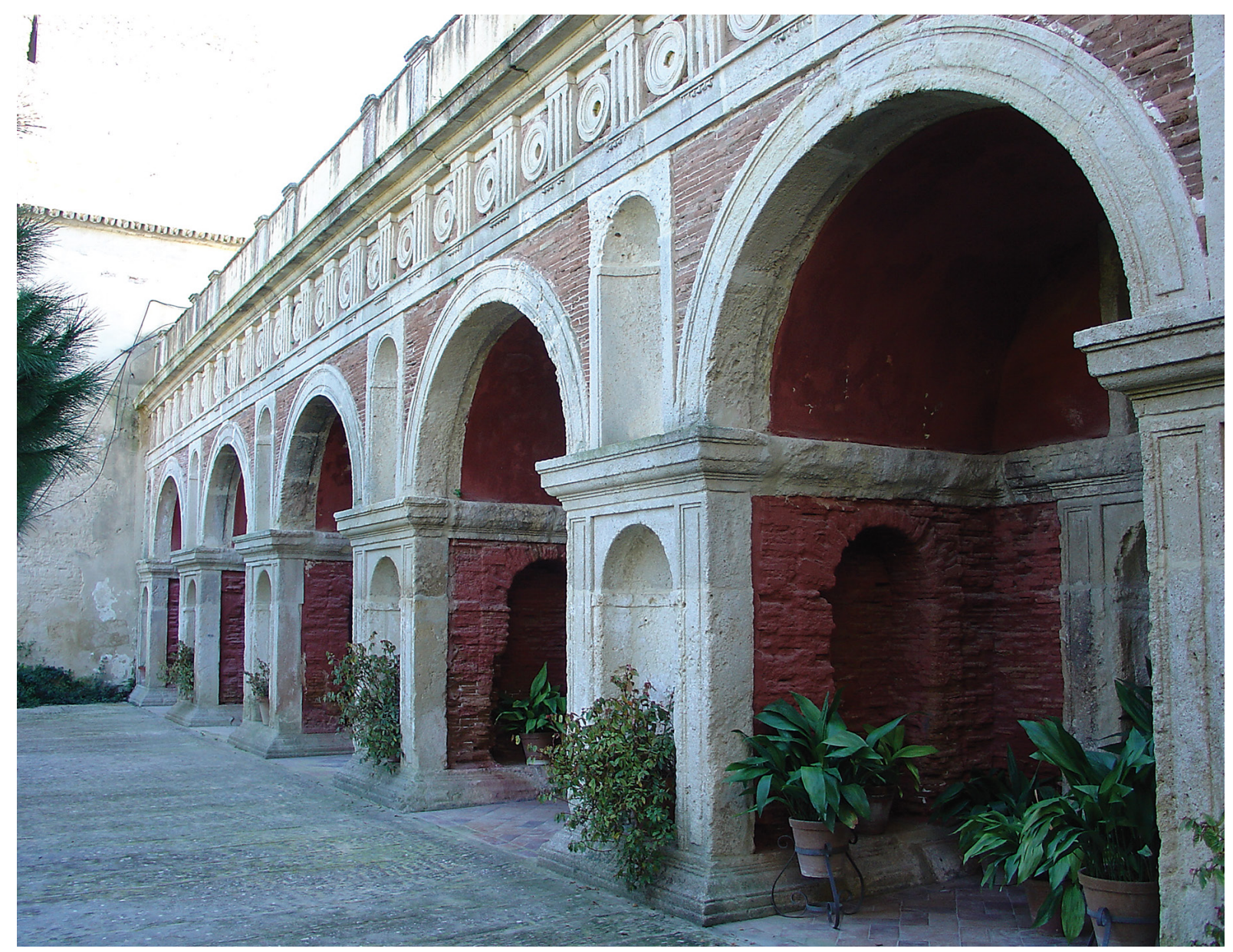

Figura 4. Muro con nichos para esculturas en el frente de los jardines del palacio de los Duques de Alcalá en Bornos.

el texto de Alejandro del Barco, aunque para nuestra suerte añade en ocasiones algún mínimo detalle en la descripción de dichas esculturas, que siempre es de utilidad (Ponz 1792: 218).

También visitó el Alcázar Nicolás de la Cruz y Bahamonde, conde de Maule, con la intención de conocer las colecciones de Bruna y "anotar lo más particular" de ellas. Pero cuando llegó acababa de fallecer Francisco de Bruna, "con lo cual de orden de la corte se recogió y encaxonó todo sin haber podido lograr yo mis deseos de trasmitir a la posteridad la memoria de estas preciosidades" (Cruz y Bahamonde 1813: 240). Aun así tuvo ocasión de visitar el salón bajo del palacio gótico, donde se encontraban los cuadros procedentes de los edificios de la Compañía de Jesús tras su expulsión de España y la "Colección de Antigüedades de la Bética" que reuniera Francisco de Bruna. De esta cita algunas piezas reconocibles, como la estatua de Trajano, "de todas las quales me dicen que habia formado una relación el Sr. Bruna conservador de estas antigüedades, que no he podido ver con motivo de su fallecimiento" (Ibíd.: 242), relación que podemos dar desgraciadamente por desaparecida.

Tras la muerte de Bruna en 1807, la colección quedó abandonada. La Academia de Buenas Letras, que siempre se había sentido muy vinculada a la colección formada por Bruna, fue desalojada del salón que ocupaba en el Alcázar tras la invasión francesa, quedando tras la guerra en una situación que hizo casi desaparecer a esta noble institución: “desde entonces quedó suspensa y perdió el caudal de arqueología y numismática con que había establecido en el Alcázar un hermoso museo" (Madoz 1846-50: XIV: 361). No se volvió esta Academia a reunir hasta 1820 (Aguilar Piñal 1966: 182184). Tal vez tras todos estos años se comenzó ya a perder memoria del origen de las piezas de la colección del Alcázar, y comenzó a atribuirse a todo el conjunto un origen italicense, aunque realmente su procedencia 
correspondía a otros muchos lugares de Andalucía occidental a los que lograba tener acceso Francisco de Bruna, como ya tuvimos en el pasado ocasión de mencionar (López Rodríguez 2010: 130).

El caso es que la creencia en el origen italicense de las piezas de esta colección del Alcázar fue la que se impuso a la hora de hacer el inventario del Museo de Antigüedades en 1880. Nadie recordaba ya la colección de Juan de Córdoba Centurión, y cuando Antonio Aguilar y Cano quiso buscar estas esculturas en el museo sevillano para documentar su libro Memorial Ostipense, no las pudo encontrar (o reconocer) y dejó dicho un lacónico "No hemos visto allí las estatuas que se nos ha dicho, no sabemos con qué fundamento, que están en Umbrete" (Aguilar y Cano 1886: 55).

Pues bien, como se dijo más arriba, todo lo del Alcázar pasó en 1855 al Museo de Pinturas, formando parte de lo que la Comisión Provincial de Monumentos reunía a fin de formar un museo arqueológico en Sevi1la. Así fue como se integraron las piezas de escultura y epigrafía del museo de Juan de Córdoba Centurión en lo que años más tarde sería el Museo Provincial de Antigüedades de Sevilla.

Hemos podido identificar la escutlrua REP-107 del Museo Arqueológico de Sevilla como procedente de la colección de Juan de Córdoba. Quisiéramos ahora atrevernos a hacer una propuesta de identificación del resto de las esculturas de dicha colección, en el convencimiento de que, aunque olvidadas e ignoradas, dichas esculturas han estado siempre formando parte del $\mathrm{Mu}$ seo Arqueológico de Sevilla desde sus inicios.

La tarea no debería ser excesivamente difícil ya que contamos con las ilustraciones del manuscrito, a lo que hay que añadir que las piezas que buscamos tienen que encontrarse dentro de la colección del Museo Arqueológico de Sevilla entre las 335 primeras del inventario que realizó Manuel Campos Munilla en 1880 al hacerse cargo del mismo. Es más, dentro de estas 335, dichas piezas han de encontrarse entre el número 93 y el número 188, que son las esculturas en dicho inventario. Esto limita considerablemente la búsqueda, especialmente si tenemos en cuenta además que muchos de estos números de inventario corresponden a pequeños fragmentos de estatua, descartables a la hora de buscar la identificación de las esculturas representadas en el manuscrito. El abanico de piezas a elegir no es muy amplio, por lo que no debería ser difícil encontrar entre el limitado número de esculturas de la colección inicial las que coinciden con las características descritas y dibujadas por nuestra principal fuente, el manuscrito de Alejandro del Barco.

\section{LA PRIMERA ESTATUA (REP 131)}

La primera estatua tanto para San Román como para Alejandro del Barco es la conocida como una representación de Hércules, atribución que viene de antiguo. Alejandro del Barco la describe así: "La estatua es de piedra bastantemente sólida de color blanco algo sucio. El vulto de medio relieve, y por la estatura y dimensión gigantescas, la piel de león que tiene a las espaldas cuya cabeza se descubre por cima del hombro izquierdo, claramente se conoce que es simulacro del famosísimo Hércules" (Barco 1994: 220). La figura que ilustra esta descripción representa un torso de hombre hasta por debajo de la cintura, con los antebrazos seccionados y cabeza de frente, pelo rizado y bigote. Sobre su hombro izquierdo aparece una cabecita de león cuya piel debía caer en la espalda, asomando el pelamen de la misma y una garra por los costados (fig. 5).

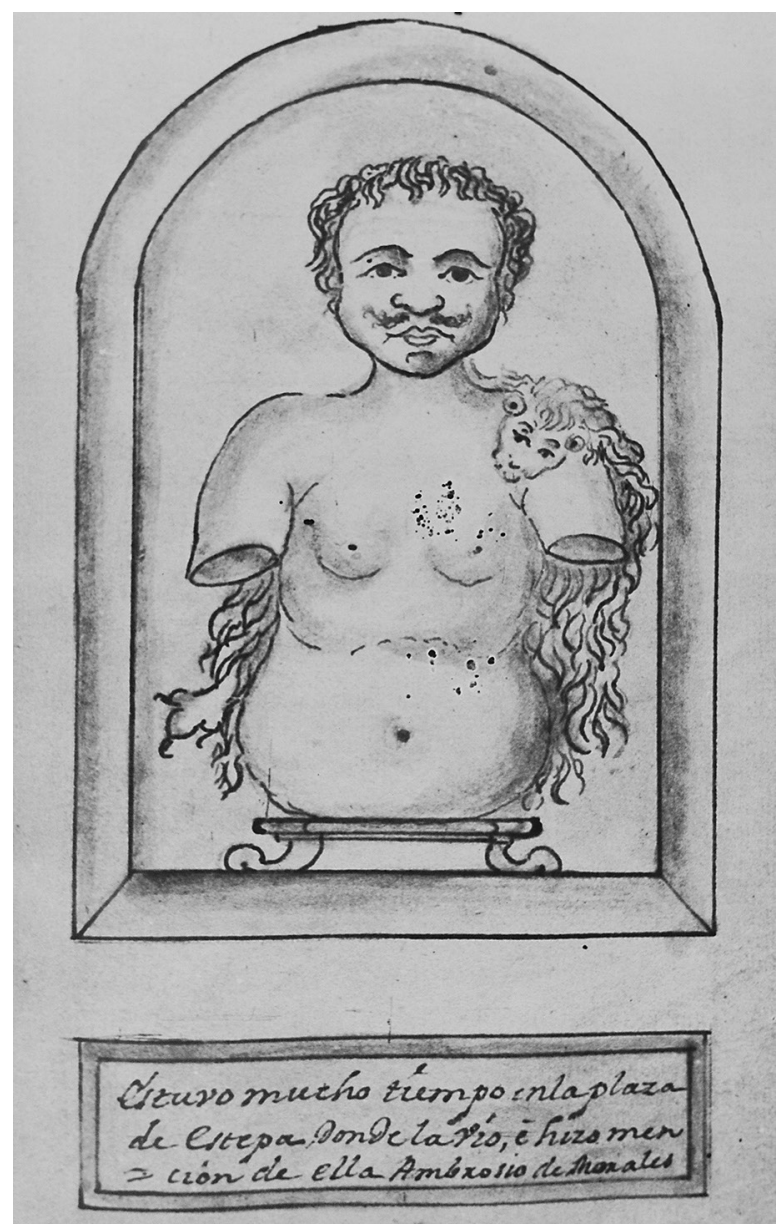

Figura 5. Estatua primera de la colección de Lora de Estepa, representando la figura de Hércules, según Alejandro del Barco. 


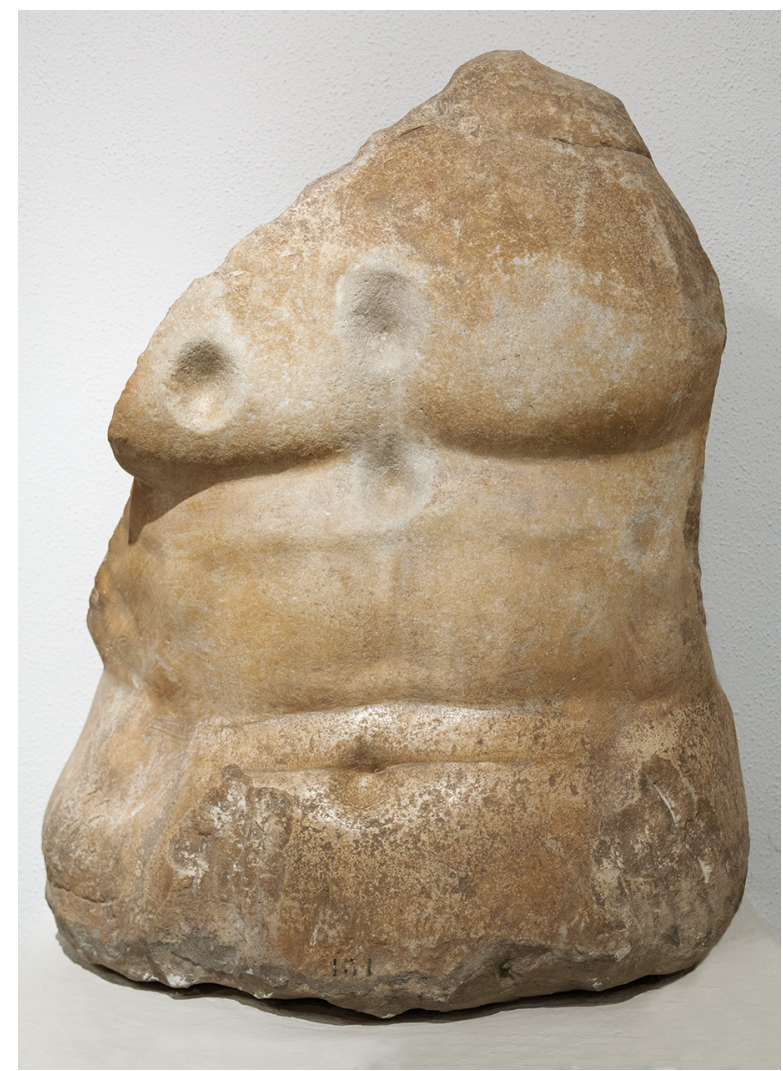

Figura 6. Escultura colosal en la colección del Museo Arqueológico de Sevilla. REP 131.

Al pie de la figura dice la cartela que junto a ella puso Juan de Córdoba: "Estuvo mucho tiempo en la plaza de Estepa, donde la vio e hizo mención de ella Ambrosio de Morales".

En efecto, esta pieza estuvo en la plaza de Estepa desde tiempo inmemorial, y al referirse a ella Ambrosio de Morales, en su obra Las antigüedades de las ciudades de España dice: "La más insigne antigualla de todas las que allí ay, es un Hércules de mármol que está en la plaza, y aunque está quebrado se parece bien en él su grandeza y gentil arte con que fue esculpido" (1575: 81v).

En aquella plaza permaneció hasta 1659 en que con fecha 16 de junio se presentó al cabildo de la ciudad de Estepa una petición en nombre de Juan de Córdoba para que fuera trasladada al palacio de Lora (Aguilar y Cano 1886: 54). Juan de Córdoba se refería a esta estatua como "la ídola que llaman que es Júpiter, digo, Hércules que trae Ambrosio de Morales" (Carta de Juan de Córdoba a Martín Vázquez Siruela, citado en Ballesteros Sánchez 2002: 228).
Creemos que esta escultura se corresponde con la pieza del Museo Arqueológico de Sevilla que lleva por número de inventario REP-131 (fig. 6). Se trata del fragmento del torso de una escultura colosal en la que destaca su musculatura. Es de mármol blanco que ha adquirido una pátina amarillenta y alcanza lo conservado una altura de poco más de un metro, desde su hombro izquierdo hasta aproximadamente la línea del pubis. $\mathrm{Su}$ estado de conservación es malo pues la pieza se halla rota y erosionada, presentando la parte trasera una rotura de forma cóncava. Además presenta en el frente varias concavidades debidas a la erosión, aparentemente por goteo de agua, lo que indica que ha estado a la intemperie un largo periodo de tiempo, expuesta cara arriba, tal vez antes de ser colocada en la plaza de Estepa. Otra rotura arranca del hombro izquierdo hasta la cintura, y por abajo los costados de la piedra están redondeados de forma que llaman la atención, lo que ha servido a Pilar León para suponer que se trata de un acrolito de una figura sentada y que este torso iría encajado por la zona redondeada en otra pieza (León 1995: 54).

Se puede pensar que hay un gran trecho entre esta escultura y el dibujo de la misma que presenta el manuscrito de fray Alejandro del Barco, donde la figura es más completa y tiene la cabeza de león en el hombro izquierdo. No tenemos explicación para esta cabeza de Hércules con bigote, ni para la cabeza de león con su piel y garra, salvo que todo ello sea un añadido a la figura para justificar su identificación como Hércules, si es que existieron estas adiciones más allá del dibujo de Del Barco. Es cierto por otro lado que Ponz en su texto (1792: 218), alude también a la piel de león, y luego a la inscripción que acompañaba ("Estuvo mucho tiempo en la plaza de Estepa", etc.), lápida que no se conserva, por lo que pensamos que simplemente está tomando la referencia del texto de Alejandro del Barco. Tampoco podemos descartar que la rotura de la pieza sea posterior al siglo XVIII y que se haya perdido algún vestigio de la piel de león.

A pesar de todo ello, es preciso señalar que existen sin embargo semejanzas notorias entre el dibujo y la escultura del museo que proponemos, como la masa musculosa en visión frontal, los dos pectorales señalados, el pliegue sobre el abdomen, el ombligo y, sobre todo, la forma redondeada de la parte inferior de la escultura. Incluso los puntos que jalonan el torso en el dibujo podrían corresponder figuradamente a los huecos efectivos que la pieza presenta a consecuencia de la erosión. Contribuye además a respaldar nuestra atribución el hecho de que no existe en el Museo Arqueológico de Sevilla otra escultura que se adecue tan cumplidamente 
a las características de esta primera de la colección de Juan de Córdoba Centurión.

Y no se nos puede pasar por alto que ya Ambrosio de Morales dice de este torso que "está quebrado", como realmente lo está el que decimos, y que por otro lado Juan de Córdoba Centurión, al hablar de esta "idola", lo llama Júpiter o, corrige, Hércules, lo que prueba que ya en el siglo XVII no eran tan evidentes los atributos hercúleos de esta escultura, como el león.

Para nosotros es claro que el torso colosal del $\mathrm{Mu}-$ seo Arqueológico de Sevilla (REP 131) se puede identificar con la representada como "primera estatua" de la colección de Lora de Estepa, atribuida a Hércules en el manuscrito.

\section{LA SEGUNDA ESTATUA (REP 107)}

Es la escultura thoracata que hemos tratado ampliamente páginas más arriba. Fray Alejandro del Barco dice de ella:

"Esta es una estatua de vulto entero primorosamente labrada. La piedra es dócil de color pardo; tiene más de vara de alto y está algo maltratada no solo del temporal a que se halla expuesta, como las demás, sino es también de las gentes que no saben el aprecio que estas Antigüedades se merecen" (...) "No es fácil determinar qué sugeto representa dicha estatua porque aunque su disposición armada pudiera aludir a Marte, no es bastante esto, sin otro algún indicio para hacer semejante contracción" (...) "Los vecinos de Lora, que son gentes sencillas, y sin más cultura que la de sus huertas, le llaman el Gran Pompeyo. Y a la verdad, la figura y disposición de la estatua no desdice de la condición de un Héroe, que apenas vistió otra gala que las armas, con que triunfó de Sertorio, y dio que temer a Cesar, haciéndose digno de muchas estatuas" (Barco 1994: 222-224).

En el manuscrito de San Román Muñoz existe una representación de esta escultura, aunque pensamos que muy alejado de la realidad, pues con su yelmo, escudo y lanza, más parece ilustración para el Quijote de Cervantes (San Román Muñoz 1716: 395r).

\section{LA TERCERA ESTATUA (REP 138)}

Dice Alejandro del Barco de esta escultura: "La figura que antecede es igualmente de vulto entero, de la misma calidad de piedra y más de vara de alto. Está más destrozada que las dos que la preceden". La

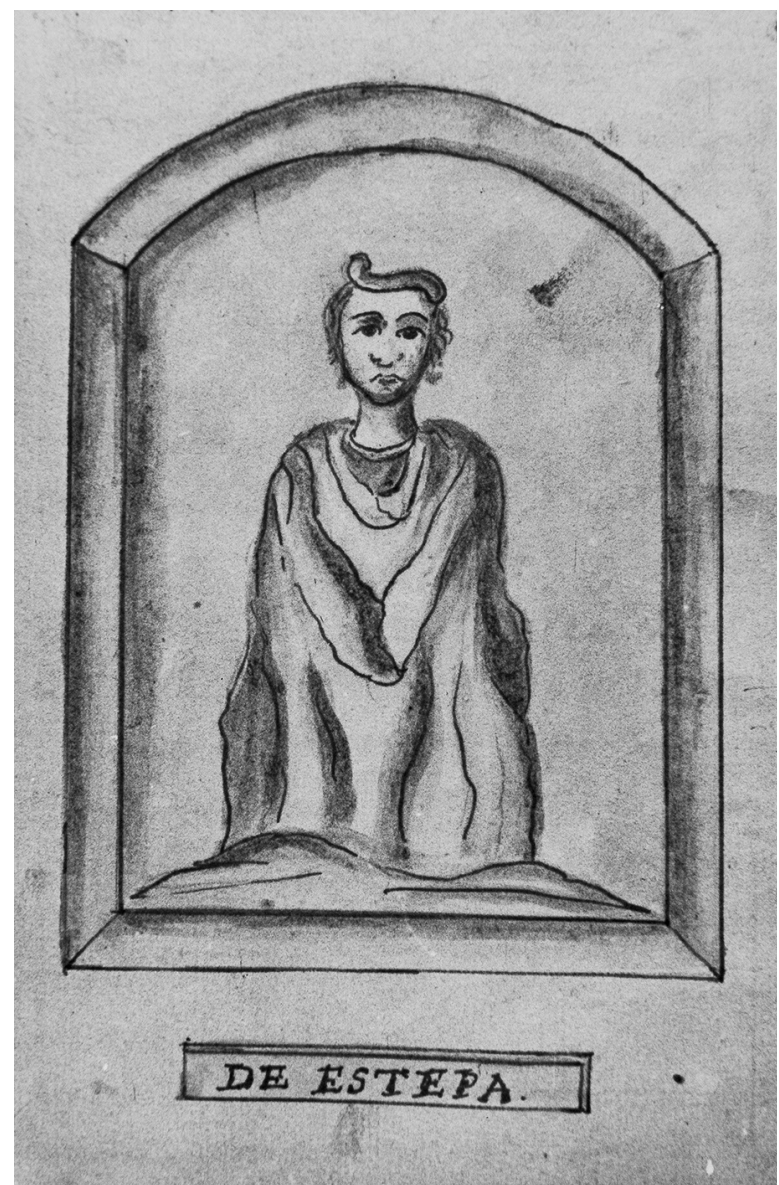

Figura 7. Tercera escultura en la colección de Lora de Estepa, dibujado por Alejandro del Barco.

ilustración de esta escultura en el manuscrito de fray Alejandro del Barco muestra una figura cercenada en su parte inferior, que se apoya en una superficie irregular, tal vez reflejo del suelo lleno de escombros del palacio en ruinas. Tiene cabeza, la cual muestra un extraño peinado, y está completamente vestida, siendo de destacar los pliegues de su ropaje, identificado como toga, que desde el cuello y los hombros forman pico hacia el centro de la figura (Barco 1994: 225-226) (fig. 7). Antonio Ponz en su descripción añade algún detalle a lo dicho por Barco: "En el tercero había otro bulto con ropage talar, de más de medio cuerpo; pero no es fácil determinar si es toga o pretexta: tiene los brazos truncados por los hombros" (Ponz 1792: 218).

Respecto a la cabeza, Del Barco dice lo siguiente:

"Dos años ha que la vi, conservaba la cabeza sobre la que tenía una figura de cubierta semejante a la que poníamos en la estampa, que por lo mismo es 


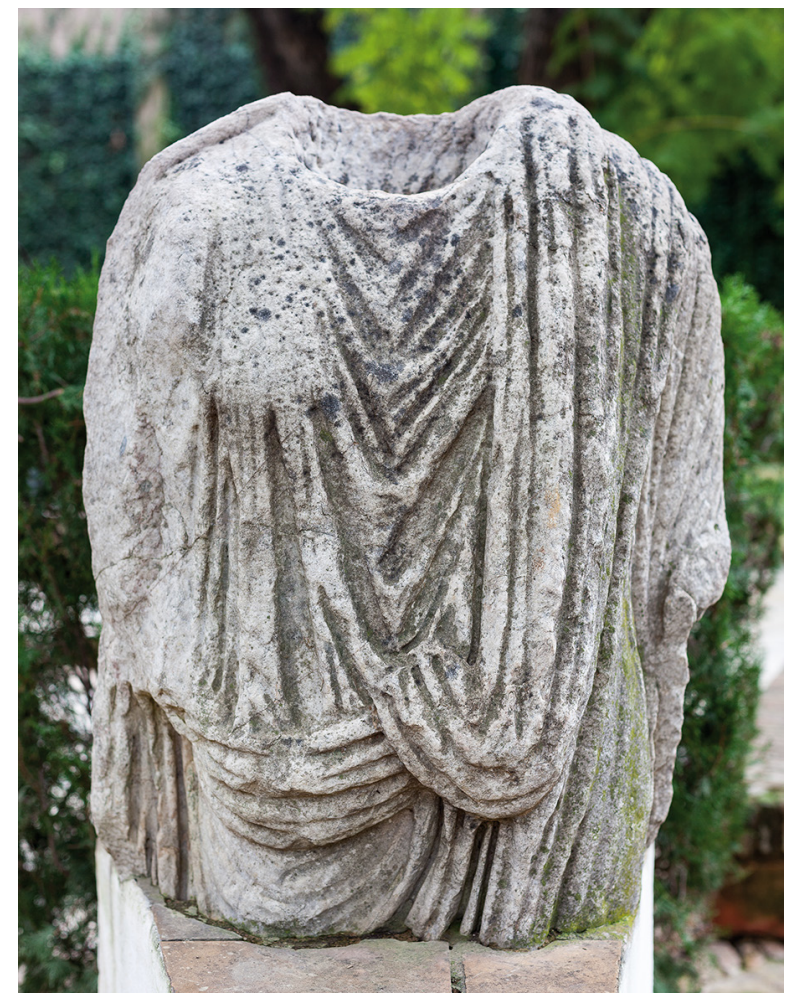

Figura 8. Escultura representando un togado. Número de registro REP 138, en su ubicación actual de los jardines del Alcázar de Sevilla.

difícil poder explicar lo que es, y más teniendo muy desportillada toda la superficie. Ya me aseguran que le falta la cabeza. Que no se sabe si por haberla extraído de allí o por habérsele caído con el tiempo, y que ande rodando en el sitio entre los muchos escombros y broza de que está cubierto. He hecho el encargo de que practiquen la diligencia de buscarla, para que no se pierda; pues es más verosímil que se le haya caído con el tiempo, que no que haya sido hurtada, atento a que estaba maltratada, como dixe, y de poca codicia para los que hoy hacen comercio o trato lucrativo de semejantes antiguallas".

Es muy interesante este comentario. La cabeza, que en esta escultura era pieza aparte, podría haber sido la original, y es de lamentar que se haya perdido. Pero también nos queda la duda de que pudiera ser un añadido. No olvidemos que las dos primeras esculturas que hemos tratado también ostentan en los dibujos su cabeza, y que en ambos casos estas presentan unos rasgos en cierto modo "fuera de época", como el bigote en la de Hércules, o el morrión con plumas en la del militar. Cabe la posibilidad, como ya hemos apuntado anteriormente, de que todo se redujera a unos aditamentos, en el dibujo o al natural, para dar verosimilitud a la identificación de los personajes que participan de la escenografía del muro de los nichos de Lora.

A pesar de lo impreciso del dibujo del manuscrito de Alejandro del Barco, creemos que de entre las esculturas del Museo Arqueológico de Sevilla la única escultura que corresponde a esta tercera estatua es la que lleva de número de inventario REP 138 (fig. 8).

Se trata de una pieza de mármol grisáceo, regularmente conservada, representando un personaje togado del que se conserva desde el cuello hasta casi la mitad de los muslos. Su altura es de $90 \mathrm{~cm}$, lo que casa bien con el "más de vara de alto" de la descripción antigua. La cabeza, perdida, era pieza aparte y se muestra el hueco para el encaje. Los brazos se hallan aparentemente por debajo de la vestidura, rotos cerca de la altura de los codos, siendo el lado derecho más difícil de reconocer por causa de la erosión. Viste túnica que ofrece sobre el pecho unos pliegues angulosos desde el cuello a la cintura, donde junto a un umbo de pliegues también angulosos aparece un balteus ancho y caído, en una curva que antecede los primeros pliegues del si$n u s$, interrumpidos por la rotura de la pieza.

Curiosamente, esta escultura no se conserva actualmente en la colección del Museo Arqueológico de Sevi1la. En 1947, por causa de que se estaba restaurando en el Alcázar de Sevilla una zona en la parte moderna de los jardines, llamada "de las praderas", el conservador de dicho monumento, Joaquín Romero Murube, con fecha 17 de febrero solicitó en depósito "para su exorno algunas piezas de piedra que reúnan un mínimo de cualidades decorativas y, a ser posible, arqueológicas dado el histórico recinto en que han de ser situadas". Por ello se seleccionaron 10 fragmentos escultóricos que se consideraban de menor interés arqueológico. El director del museo, Juan Lafita y Díaz emitió informe favorable con fecha de 20 de febrero, completándose la tramitación con la orden ministerial correspondiente firmada por el director general de Bellas Artes, Juan Contreras, marqués de Lozoya, con fecha 10 de marzo de 1947. El 18 de marzo se procedió a la entrega, levantándose la prescriptiva acta de depósito. Con este motivo se dio de baja a dichas piezas en el inventario general del museo. Como es habitual, el depósito no trasmitía la titularidad, "bien entendido (así dice la propia orden ministerial) que la duración del depósito en su totalidad o parte queda supeditada a los intereses de aquel (el museo), debiendo ser atendidas las indicaciones que la dirección del Museo o la Inspección pudieran hacer acerca de la mejor conservación de las piezas" (Archivo del Museo Arqueológico de Sevilla, Caja 89). 


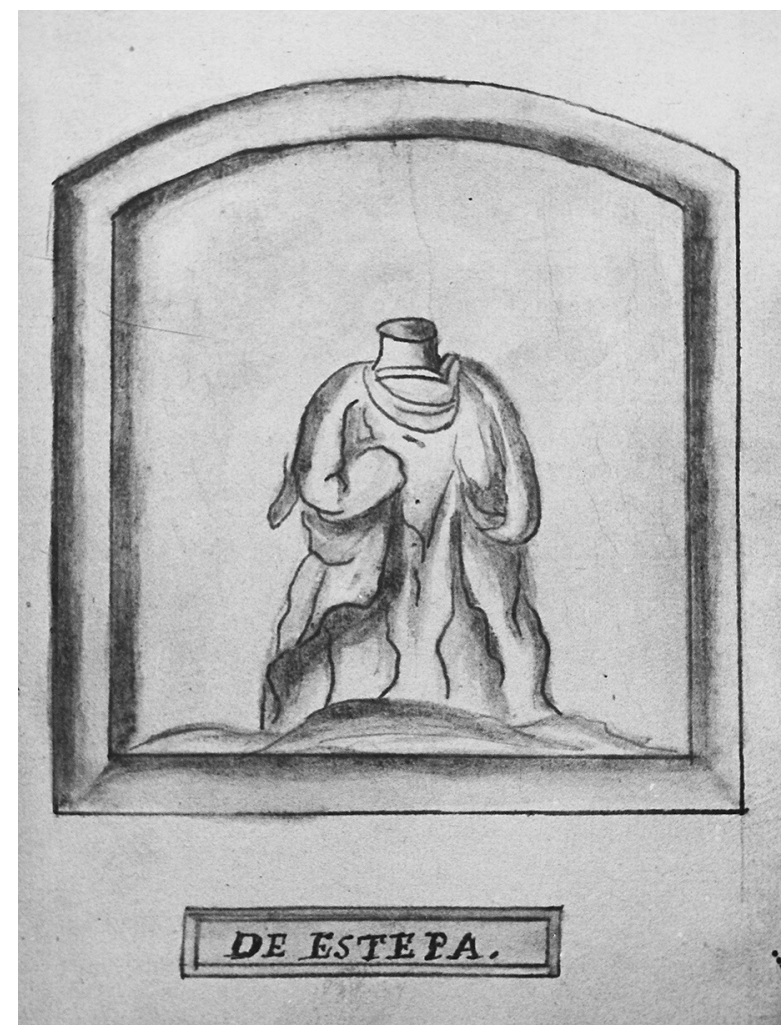

Figura 9. Estatua cuarta según el manuscrito de Alejandro del Barco.

\section{LA CUARTA ESTATUA}

Dice Antonio Ponz de esta escultura: "También está sin cabeza ni brazos el bulto del cuarto nicho, aunque los brazos parece que los oculta el ropage talar y la figura tiene cosa de una vara de alto" (Ponz 1792: 2018). El dibujo que nos presenta Del Barco tampoco es muy preciso, dentro del estilo a que nos tiene acostumbrados este autor, aunque en este caso hay un detalle significativo que destaca, y es la postura de los brazos. Se trata de una figura vestida, con los brazos bajo la ropa dirigidos hacia el centro del pecho, a la que le falta la parte inferior y que, como en el caso anterior, se levanta sobre un suelo irregular que pensamos pueden ser los escombros del lugar (fig. 9). De ella dice este autor: "La estatua de que tratamos hace muchos años que la vi sin cabeza, y por lo que respecta al tronco del cuerpo, aún está más mal tratada que las que dejamos referidas".

Solamente existe en la colección del Museo Arqueológico de Sevilla una escultura cuya forma y postura de brazos sea semejante a la representada. Se trata de una estatua femenina vestida con stola y palla cuyos pliegues se recogen hacia el centro de la figura (fig. 10). Ha sido estudiada por Pilar León, que propone para ella una cronología de época augustea (1995: 62).

En esta mencionada publicación figura que esta pieza tiene en el museo el número de registro REP 3.152. Sin embargo ya hemos comentado más arriba que el núcleo de esculturas fundacional del museo abarca desde el número 93 al número 188, por lo que este número referido está fuera de rango. Todo ello se debe simplemente a algún comprensible error en los datos que en su día se le facilitaron a esta investigadora, lo que habrá de estudiarse en otra ocasión.

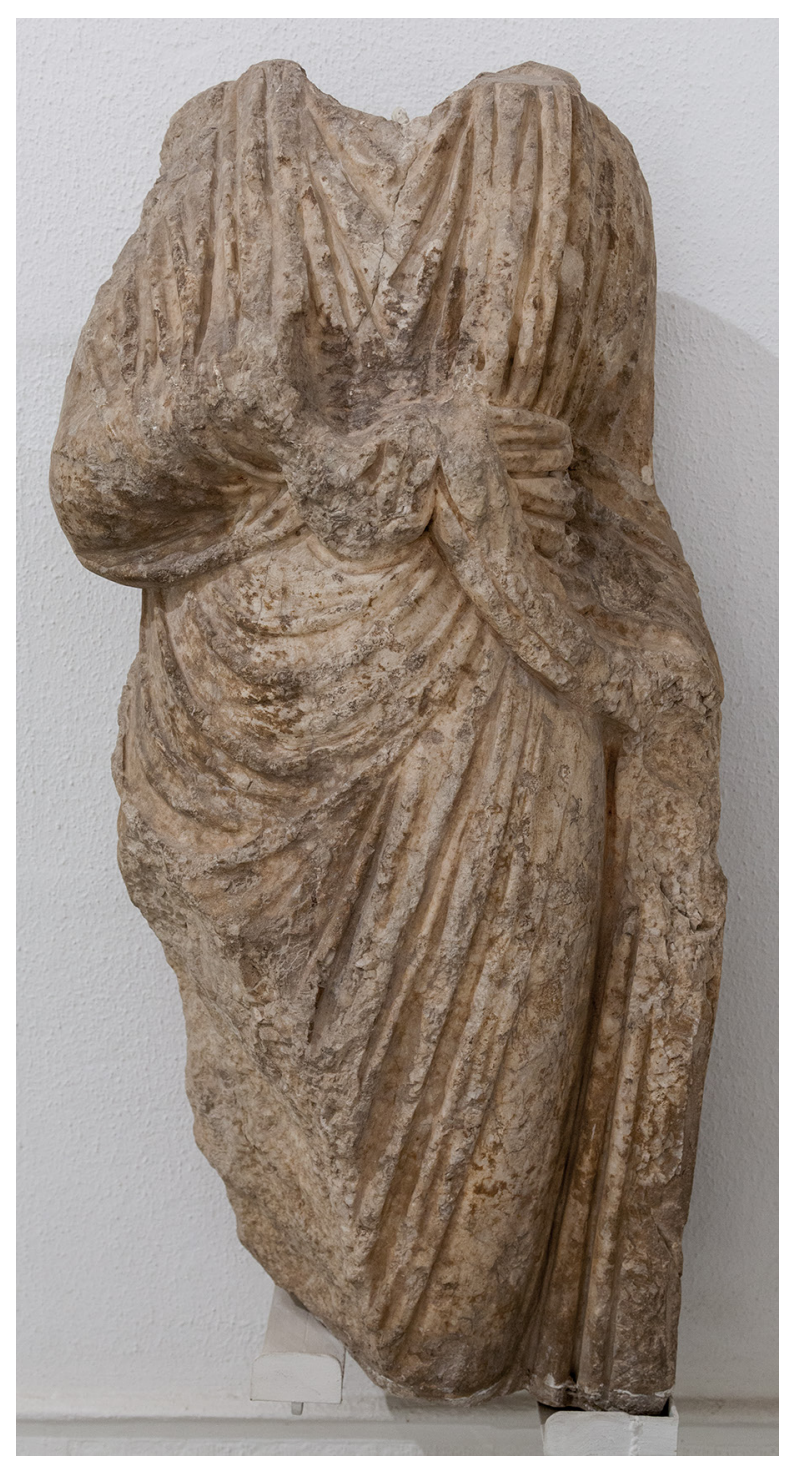

Figura 10. Escultura femenina del Museo Arqueológico de Sevilla. 


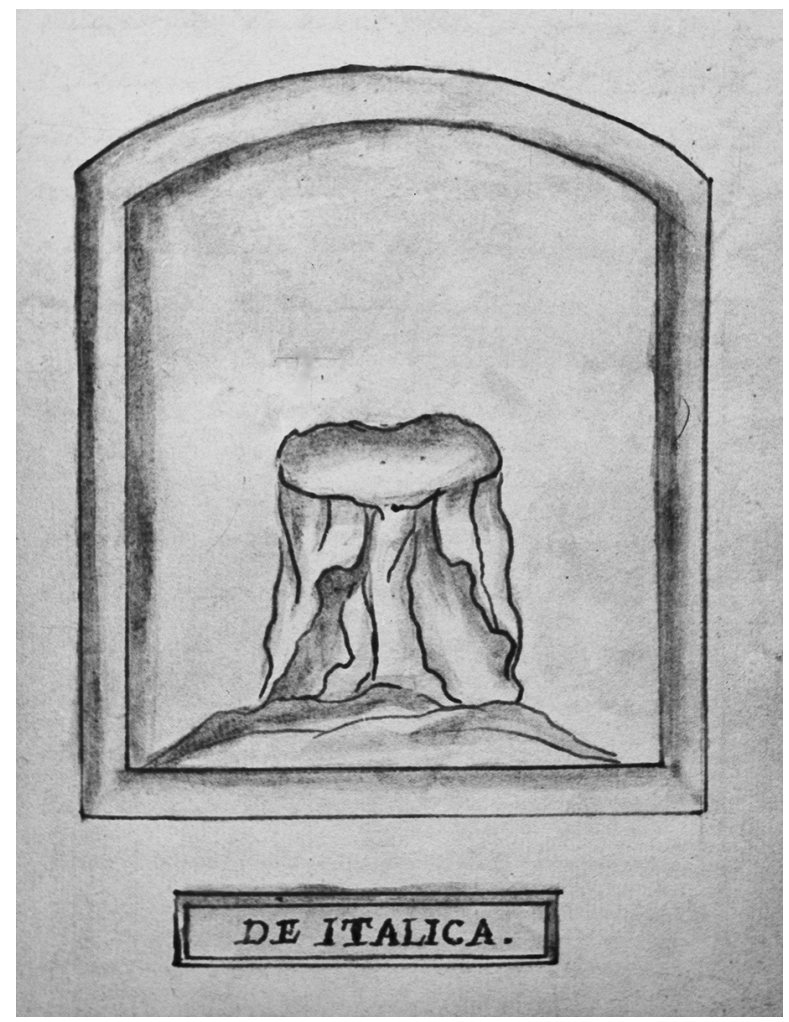

Figura 11. Estatua quinta de Lora de Estepa, según dibujo de fray Alejandro del Barco.

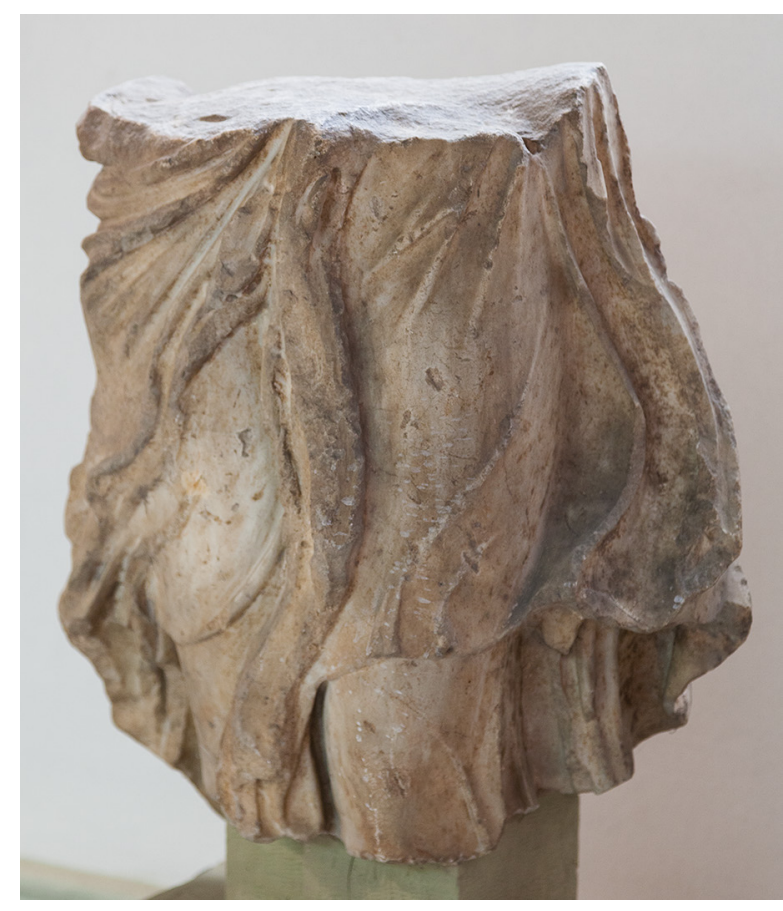

Figura 12. Escultura con número REP-119 del Museo Arqueológico de Sevilla.

\section{LA QUINTA ESTATUA (REP 119)}

A diferencia de las demás esculturas de esta colección, la quinta es la única que no procede del marquesado de Estepa, sino de un lugar tan alejado como Itálica. Este hecho lo considera Alejandro del Barco un completo contrasentido, pues entra en contradicción con la intención del creador del museo, el cual según la lápida fundacional, "recogió con esmero estos fragmentos mutilados de los tiempos antiguos, esparcidos violentamente por el territorio de Estepa", según la traducción de la misma que hizo José Gestoso (1910: 281). Por ello fray Alejandro del Barco añade: "es de creer vendría la estatua entera, porque un trozo tan informe, como hoy se ve, no merecia traerse a toda costa tantas leguas de distancia" (Barco 1994: 231).

Según el mismo autor,

\begin{abstract}
"este es un fragmento que al paso que su destrucción nos priva de toda luz para poder tratar del, nos hace ver con la mayor claridad el desprecio y abandono con que se han mirado estos Monumentos de Antigüedad, después que faltó el que tuvo el gusto y curiosidad de recogerlos. Es un trozo de Estatua, que solo indica que su adorno era de vestidura talar, como las dos que le anteceden" (Barco 1994: 229-230).
\end{abstract}

La figura que ilustra esta descripción es la de un tronco de estatua en el que unas líneas irregulares señalan torpemente las vestiduras. De nuevo está sobre un suelo que podría representar los escombros caídos en el lugar (fig. 11).

Como en una ocasión anterior, Antonio Ponz añade un dato interesante a la escasa descripción que hasta ahora poseíamos: "La del quinto nicho es un fragmento desde la cintura hasta las rodillas con corta diferencia, y ropage talar como las anteriores, debajo dice, de Itálica" Y añade: "Todos estos fragmentos se hallan colocados en la galería que da ingreso a los salones del Alcázar" (Ponz 1792: 218).

Los datos que teníamos, dibujo incluido, hacían muy difícil una identificación de esta pieza italicense. Sin embargo el dato añadido por Ponz al decir "desde la cintura hasta las rodillas", nos anima a proponer para esta escultura la pieza REP 119 del Museo Arqueológico de Sevilla. Se trata de un fragmento de escultura femenina de mármol, de $53 \mathrm{cms}$ de alto, desde la cintura hasta poco más abajo de las rodillas, cuyas vestiduras caen en pliegues irregulares que expresan movimiento y traslucen el modelado de la anatomía (fig. 12).

Este fragmento de escultura presenta la rotura de la parte superior en forma de sección plana, semejante 
a como se muestra en el dibujo mencionado, lo cual puede ser un argumento a considerar. No sabemos qué personaje puede representar, tal vez sea una Victoria, como reza la cartela situada junto a la obra en la sala del museo donde se expone.

\section{A MODO DE RESUMEN Y CONCLUSIÓN}

Una vez que hemos concluido la revisión de los datos historiográficos que afectan a las esculturas estudiadas más arriba, queremos concluir haciendo un repaso a todo lo visto en este texto, cuyo fin último era ahondar en los orígenes del Museo Arqueológico de Sevilla a través de sus colecciones. Este museo se creó oficialmente por real orden de 21 de noviembre de 1879 , como una consecuencia tardía del real decreto de 20 de marzo de 1867 que, a la par del Museo Arqueológico Nacional, creaba un museo arqueológico en cada capital de provincia.

Sin embargo desde antes de la mitad del siglo XIX, las instituciones sevillanas habían intentado de diversas maneras crear un museo arqueológico en esta ciudad, aunque sin unos resultados plenamente satisfactorios. En este sentido comenzaron a trabajar tanto la Comisión Provincial de Monumentos como la Real Academia Sevillana de Buenas Letras.

Tanto una como otra aspiraron a gestionar dos importantes colecciones arqueológicas preexistentes. Una era la que permanecía en el Alcázar de Sevilla, formada por Bruna, consistente esencialmente en esculturas y lápidas. La otra era la que se estaba formando en las dependencias del Gobierno Político de la ciudad, como consecuencia de las excavaciones que Ivo de la Cortina realizaba en Itálica, aprovechando los descubrimientos que se estaban produciendo tras los destrozos ocasionados por la construcción de la carretera de Extremadura a su paso por Santiponce.

En esta segunda colección estaba muy interesada la Real Academia de Buenas Letras, habiendo reclamado su cesión al gobernador civil en varias ocasiones. No en vano Ivo de la Cortina era miembro de esta Academia, la cual tenía además el encargo de la Junta de Gobierno de la Provincia de Sevilla de dirigir las excavaciones de Itálica. A pesar de ello, una real orden de 4 de diciembre de 1840 determinaba que el Museo de Antigüedades se formase junto al Museo de Pinturas, gestionado por una Junta de Museo ajena a la Real Academia. Esta Junta de Museo será la que reciba los objetos del Gobierno Político en 1842.

Por otro lado, una vez creada en 1844 la Comisión Provincial de Monumentos Históricos y Artísticos de
Sevilla, comenzó esta comisión a reclamar los objetos arqueológicos que se encontraban almacenados en el Alcázar Sevillano. Se trataba, como se ha dicho más arriba, de la colección formada por Francisco de Bruna y Ahumada, que reunía escultura y epigrafía. Si bien es verdad que algunas de las esculturas de esta colección procedían de Itálica, producto tanto de excavaciones del propio Bruna, como recogidas por los monjes de San Isidoro del Campo, otras muchas tenían su origen en diversos lugares y yacimientos de la Andalucía occidental. Entre todo ello se encontraba la colección de esculturas y epígrafes que había reunido Juan de Córdoba Centurión en Lora de Estepa. La colección del Alcázar pasó a la Comisión de Monumentos en 1855, sumándose como un segundo núcleo a lo que se encontraban ya depositado en el Museo de Pinturas. Con todo ello, que con la suma de las dos colecciones alcanzaba la cifra de 335 objetos, se formó en 1879 el Museo de Antigüedades de Sevilla.

Teníamos noticias de la existencia en cada una de estas dos colecciones precursoras del museo de sendas esculturas thoracatas, a la par que existían en las salas del museo dos esculturas thoracatas sin identificación. La comparación de las mismas y de la información historiográfica nos ha permitido por un lado identificarlas, asignándoles un contexto y una procedencia a cada una de ellas, gracias a lo cual hemos podido, con esta excusa, ahondar en el conocimiento de los primeros intentos de formación de un museo arqueológico en Sevilla en el siglo XIX.

Una de estas dos esculturas thoracatas procedía de la colección que reuniera en su palacio de Lora de Estepa Juan de Córdoba Centurión. Formaba parte de un conjunto de cinco esculturas que estaban colocadas en su palacio en un frente de nichos para estatuas en el paso del edificio a los jardines, siguiendo el modelo de ensayado en Bornos para los duques de Alcalá. Tanto de esta escultura thoracata, como de las otras cuatro estatuas de la colección, se había perdido toda memoria, atribuyéndose de forma genérica su procedencia a Itálica. Gracias a que fueron representadas en un manuscrito del siglo XVIII firmado por Alejandro del Barco, y de que fueron citadas por otras fuentes, creemos que hemos podido identificarlas entre las piezas que se encuentran en el museo hoy día, aportando luz a una faceta olvidada de los orígenes del Museo Arqueológico de Sevilla

\section{Abreviaturas empleadas}

CPMHAS $=$ Archivo de la Comisión Provincial de Monumentos de Sevilla. Real Academia de Bellas Artes de Santa Isabel de Hungría. 
RASBL $=$ Archivo de la Real Academia Sevillana de Buenas Letras.

\section{BIBLIOGRAFÍA}

Acuña Fernández, P. (1975): Esculturas militares romanas de España y Portugal. I.- Las esculturas thoracatas, Roma, Consejo Superior de Investigaciones Científicas.

Aguilar Piñal, F. (1966): La Real Academia Sevillana de Buenas Letras en el siglo XVIII. Madrid, Consejo Superior de Investigaciones Científicas.

Aguilar y Cano, A. (1886): Memorial Ostipense. Estepa, Imprenta de Antonio Hermoso.

Amores Carredano, F. y Beltrán Fortes, J. (eds.) (2012): Itálica 1912-2012. Centenario de la Declaración como Monumento Nacional. Sevilla, Fundación Itálica.

Ballesteros Sánchez, J. R. (2002): La antigüedad barroca: libros, inscripciones y disparates en el entorno del III marqués de Estepa. Estepa, Diputación de Sevilla, Ayuntamiento de Estepa.

Barco, A. del (1994): La antigua Ostippo y actual Estepa. Edición, introducción y notas de A. Recio Veganzones. Estepa, Ayuntamiento de Estepa.

Calleja Marchal, E. (1999): "Jardín renacentista del Palacio Ducal de Bornos", en U. Domínguez Garrido y J. Muñoz Domínguez (coords.), Terceras jornadas sobre "El Bosque" de Béjar y las Villas de Recreo en el Renacimiento. Béjar, Grupo Cultural "San Gil”.

Canto de Gregorio, A. M. (2010): Voz "Cortina Roperto", en Diccionario Biográfico Español, tomo XIV: 818-820. Madrid, Real Academia de la Historia.

Cruz y Bahamonde, Nicolás de la (1813): Viaje de España, Francia e Italia, tomo XIV. Cádiz, Imprenta de D. Manuel Bosch.

Fernández-Chicarro, C. (1947): "La estatuaria militar romana, de época imperial, en el Museo Arqueológico Provincial de Sevilla". Memorias de los Museos Arqueológicos Provinciales, 1946: 128-136.

Fernández Gómez, F. (1998): Las excavaciones de Itálica y Don Demetrio de los Ríos a través de sus escritos. Córdoba, Publicaciones de la Obra Social y Cultural Cajasur.

Ford, R. (1855): Handbook for travellers in Spain. Londres, John Murray.

Gali Lassaletta, A. (1892): Historia de Itálica, municipio y colonia romana. Sevilla, Tipografía Enrique Bergali.
García y Bellido, A. (1949): Esculturas romanas de España y Portugal. Madrid, Consejo Superior de Investigaciones Científicas.

García y Bellido, A. (1960): Colonia Aelia Augusta Italica. Madrid, Consejo Superior de Investigaciones Científicas.

Gestoso y Pérez, J. (1910): Curiosidades Antiguas Sevillanas. Sevilla, El Correo de Andalucía.

Herrera Dávila, J. (1832): Guía de forasteros de la ciudad de Sevilla. Sevilla, Imprenta del Diario de Comercio.

Laborde, A. (1802): Description d'un pavé en mosaïque découvert dans l'ancienne ville d'Italica, aujourd'hui village de Santiponce, près de Seville, suivie de recherches sur la peinture en mosaïque chez les anciens, et les monuments en ce genre qui n'ont point encore été publiés. París, Imprenta Didot L'Ainé.

León, P. (1995): Esculturas de Itálica. Sevilla, Consejería de Cultura de la Junta de Andalucía.

López Rodríguez, J. R. (1995): "El largo camino de una colección, la lenta gestación de un museo", en AA.VV., Itálica en el Museo Arqueológico de Sevilla: 11-25, Sevilla, Consejería de Cultura de la Junta de Andalucía, Fundación El Monte.

López Rodríguez, J. R. (2010): Historia de los museos de Andalucía. 1500-2000. Sevilla, Servicio de Publicaciones de la Universidad de Sevilla.

López Rodríguez, J. R. (2012): "Itálica. Cien años de descubrimientos: 1912-2012". Itálica. Revista de Arqueología Clásica de Andalucía 2: 53-73.

Luzón Nogué, J. M. (1999): Sevilla la Vieja: un paseo histórico por las ruinas de Itálica. Sevilla, Fundación Focus-Abengoa.

Madoz, P. (1846-1850): Diccionario Geográfico-Estadístico-Histórico de España y sus posesiones de ultramar, 16 tomos. Madrid, Establecimiento tipográfico de P. Madoz y L. Sagasti.

Matute y Gaviria, J. (1827): Bosquejo de Itálica o apuntes que juntaba para su historia. Sevilla, Imprenta de D. Mariano Caro.

Morales, A. (1575): Las antigüedades de las ciudades de España. Alcalá de Henares, en casa de Juan Iñiguez de Lequerica.

Ponz, A. (1792): Viaje de España, en que se da noticia de las cosas más apreciables y dignas de saberse que hay en ella, Tomo XVII. Madrid, Viuda de D. Joaquín Ibarra.

Ríos Serrano, J. A. de los (1845): Itálica, Historia de esta ciudad famosa, desde su fundación hasta nuestros días con todos sus descubrimientos. Manuscrito, Museo Arqueológico de Sevilla, R. 3417. 
Rodá de Llanza, I. (1997): "Los mármoles de Itálica. Su comercio y origen", en A. Caballos y P. León (eds.), Itálica. MMCC, Actas de las Jornadas del 2.200 aniversario de la Fundación de Itálica: 155180. Sevilla (1994), Sevilla, Consejería de Cultura de la Junta de Andalucía.

Romero Murube, J. (1965): Francisco de Bruna y Ahumada. Sevilla, Ayuntamiento de Sevilla.
San Román Muñoz, J. de (1716): Discursos sobre la republica i ciudad antiquissima de Ostipo, i su fundacion segunda: con un sylabario de las antiguas familias della y en particular, la mui celebre y generosa del apellido noble de Muñoz / compuesto por su particular observante el P. Fr. Juan de San Román Muñoz de Estepa Calderón y Delgado. Ms. 332-141, Biblioteca de la Universidad de Sevilla. 